\title{
超高異型煙突の復元力特性に関する実験と解析 EXPERIMENTAL AND ANALYTICAL STUDY OF THE NON-LINEAR BEHAVIOR OF IRREGULAR SHAPED TALL CHIMNEYS
}

\author{
伊藤隆文*, 原田和明**, 礒 健一*** \\ Takayoshi ITOH, Kazuaki HARADA and Ken-ichi ISO
}

\begin{abstract}
The main 'factor controlling the dynamic behavior of tall chimneys during an earthquake is the non-linearity due to bending moment and shear force. In-the case of these chimneys, the structure is so simple that non-linear characteristics are strongly affected by the shape, the size of the opening, and shear span ratio. In order to make clear the effect of these factors, lateral loading $\overline{\mathrm{ex}}$ -
\end{abstract} periments were carried out on irregular-shaped reinforced concrete chimneys.

'This paper discusses the comparison between analysis by simple method and the test results. The reliability of this method for this paticular type chimney was confirmed.

Keywords : opening, chimney, non-linearity, lateral loading experiment 煙聟，開口部，水平加力実験，復元力特性，開口補強

\section{1.はじめに}

近年, 火力発電所の排ガス用煙突は, 電力の需要の増 大に伴って大型化する一方で, 大都市近郊では大気污染 防止と環境保全の面から，その高さを $200 \mathrm{~m}$ 以上に超 高化せざるをえなくなってきている。また周曲の環境と の調和を図る目的で，従来用いられてきた円筒形以外の 形状の鉄筋コンクリート煙突（以下，「超高異型煙突」 と称する。）を採用するケースが増えている。鉄筋コン クリート煙突の設計にあたって, 最も重要視されるのは 地震による挙動であるが, 煙突の場合には，その機能上， 搬入用の仮設開口と排ガス用の煙導開口を設ける必要が ありこれらの開口の寸法や位置が，単純構造である煙 突の振動特性に大きく関与する。特に, 超高異型煙突の 耐震設計では, 形状に依存する応力分布が強震時の弾塑 性挙動を決定する重要な要因となるため, 開口部を考虑 した煙突の力学特性を明確にする必要がある。

現在までに煙突を対象とした研究には, ‘表”らと武 藤 ${ }^{2)}$, 内田 ${ }^{31} ら の 一$ 連の研究があり, 日本建築学会の鉄 筋コンクリート煙突の構造設計指針 ‘ららひに日本建築 センターの煙突構造設計施工指針5)に反映されている。 これらの研究は, 円筒断面の煙突を対象として, 曲げに 関する力学特性と振動特性を明らかにしている。また, せん断に関しては, 無開口円筒断面について, せん断応 力分布と配筋法を示し, 開口部に関しては, 開口を含む
断面を 2 次元問題として扱っている。

円筒形煙突に類似した構造物では原子炬格納容器やサ イロの実験がある(6)-101。これらの構造物は一般に高さ一 幅比が小さく, せん断応力が支配的であるため, せん断 スパン比が小さい試験体を採用する場合が多く，荷重に 関しても, 内圧や温度荷重と水平力との組み合わせが多 い。

また，梅村ら ${ }^{111}$ ，遠藤ら ${ }^{12}$ は，円筒形およびボックス 形の立体耐震壁を対象とした研究を行っている。これら の研究では, ボックス形試験体の加力方向を変えた実験 を行っているが, 加力方向が斜めの場合, 最大耐力, 変 形性能が 10 20\% 上昇することを明らかにしている。 坂元らの研究 ${ }^{13)}$ では, 円筒形立体耐震壁の肉厚を変えた 実験を行っているが, 薄肉の場合最大耐力, 変形性能が 多少低下することを明らかにしている。

筆者らは, 円筒形以外の形状を呈し, 薄肉で, 複数の 開口を有し，せん断スパン比が大きく，曲げが支配的で あるが，せん断も無視することができない，超高異型煙 突特有の条件を考慮し, 開口の有無, せん断スパン比, 荷重ならびに加力方向の組み合わせをパラメーターとし た破壊実験を計画した。そしして，正負交番繰り返し水平 加力実験を行い，曲げとせん断に対する復元力特性など を明らかにし，開口部を含むシェル壁の有効高さの提案 や開口補強なよ゙, 設計への有用性と問題点を示した。

\footnotetext{
* 東電設計

** 東京電力技術研究所

*** 日本国土開発技術研究所
}

Tokyo Electric Power Services Co., Ltd.

Tokyo Electric Power Company

JDC Corporation 


\section{2. 実験計画}

\section{1 試験体}

試験体製作にあたり，実機構造物（高さ $200 \mathrm{~m} ）$ の地

表-1 1 試験体諸元

\begin{tabular}{|c|c|c|c|c|c|c|c|}
\hline & 閏口 & 妿吕 & $\begin{array}{l}\text { 㽞杂点 } \\
\text { (m) }\end{array}$ & $\begin{array}{c}\text { 全せい } \\
0 \\
(\mathrm{~m})\end{array}$ & $M / O D$ & $\begin{array}{c}\text { 到力度 } \\
0 \% \circ \\
\left(\mathrm{kg} / \mathrm{cm}^{2}\right)\end{array}$ & 喵 \\
\hline 1 & 無開口 & $90^{\circ}$ & 5.00 & 1.65 & 3.00 . & 0.0 & 曲げ破搷型 \\
\hline 2 & 無開口 & $90^{\circ}$ & 5.00 & 1.65 & 3.00 & 27.0 & 曲げ破淁型 \\
\hline 3 & 器開口 & $45^{\circ}$ & 5.00 & 2. 33 & 2.17 & 27.0 & 曲げ破撙型 \\
\hline 4 & 無開口. & $90^{\circ}$ & 1. 75 & 1.65 & 1.06 & 27.0 & せん断破擩型 \\
\hline 5 & 哭開口 & $45^{\circ}$ & 1.75 & 2. 33 & 0.75 & 27.0 & せん断破掽型 \\
\hline 6 & 有開口 & $90^{\circ}$ & 5.00 & 1.65 & 3.00 & 27.0 & 曲げ破嗄型 \\
\hline 7 & 有開口 & $0^{\circ}$ & 5.00 & 1.65 & 3.00 & 27.0 & 曲げ破㙽型 \\
\hline 8 & 有開口 & $45^{\circ}$ & 5.00 & 2. 33 & 2.17 & 27.0 & 曲げ破搂型 \\
\hline
\end{tabular}

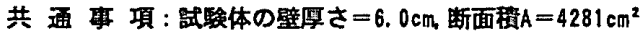

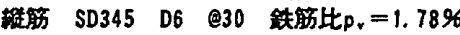
横筋 SD345 D6 B45 䣄筋比 $\mathrm{p}_{\mathrm{h}}=1.19 \%$

開口の大きさ：仮段開口 $(45 \times 50 \mathrm{~cm}$ 壁䠒)

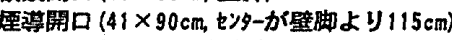

加力方向: 图一1注㹬 (a)に示した角度

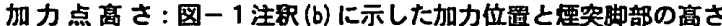

全せ い:图一1中に示す口の長さ

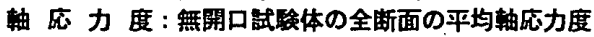

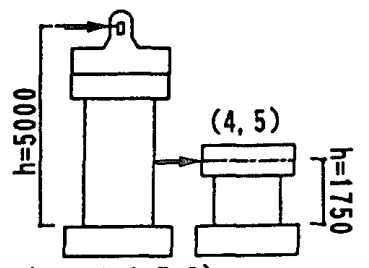

$(1,2,3,6,7,8)$
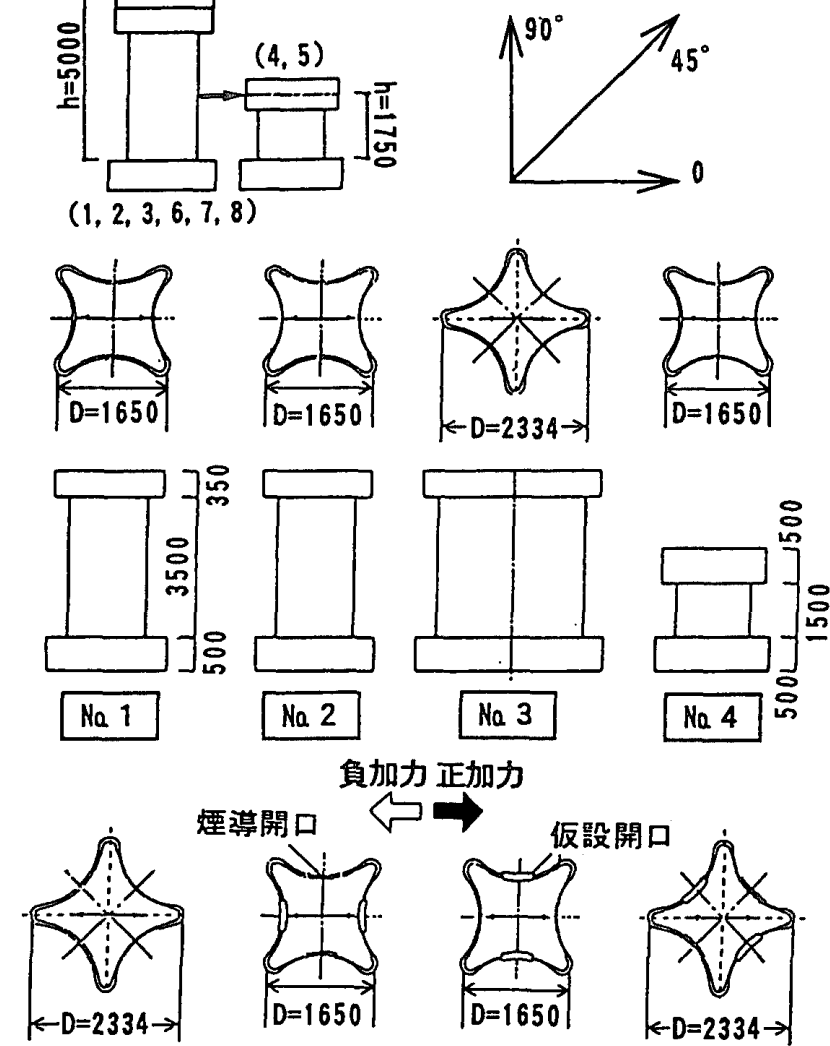

負加力 正加力
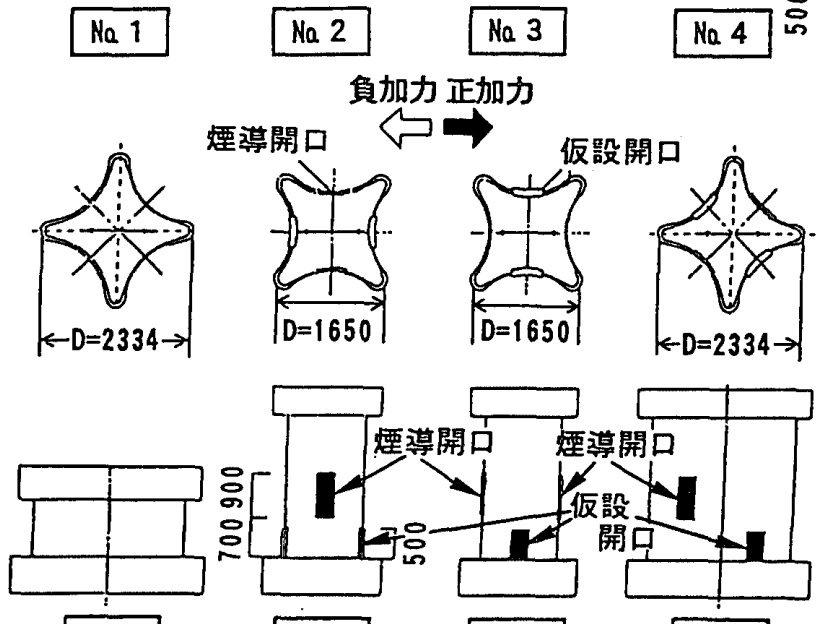

No. 5
震応答解析を実施し，最大応答値が生ずる仮設開口下端 での応答最大モーメント $(M)$ および応答最大せん断力 $(q)$ 亡,それらが生ずるそれぞれ同時刻での応答せん断 力 $(Q)$ および応答モーメント $(m)$ を求め, 実構造物の一 辺の長さ $(D)$ を梁の有効せいとし，曲げ破壊型では $M / Q D$ より，せん断破壊型では $m / q D$ よりせん断スパ ン比を求めた。試験体は実機煙突脚部の $1 / 15$ スケール の 8 体で, 開口の種類, 有無, 加力方向, せん断スパン 比，軸力の有無をパラメーターとした。また，試験体の 加力点高さ $(h)$ は, 上記の方法で求めたせん断スパン比 と，試験体でも同じせん断スパン比が得られるように決 定した。

表一 1 に試験体諸元を示し, 図一 1 に試験体の一覧, 図一 2 に試験体の配筋，形状を示す。なお，表一1中， 曲げ破壊型，せん断破壊型の判定は，表一5（実験結果
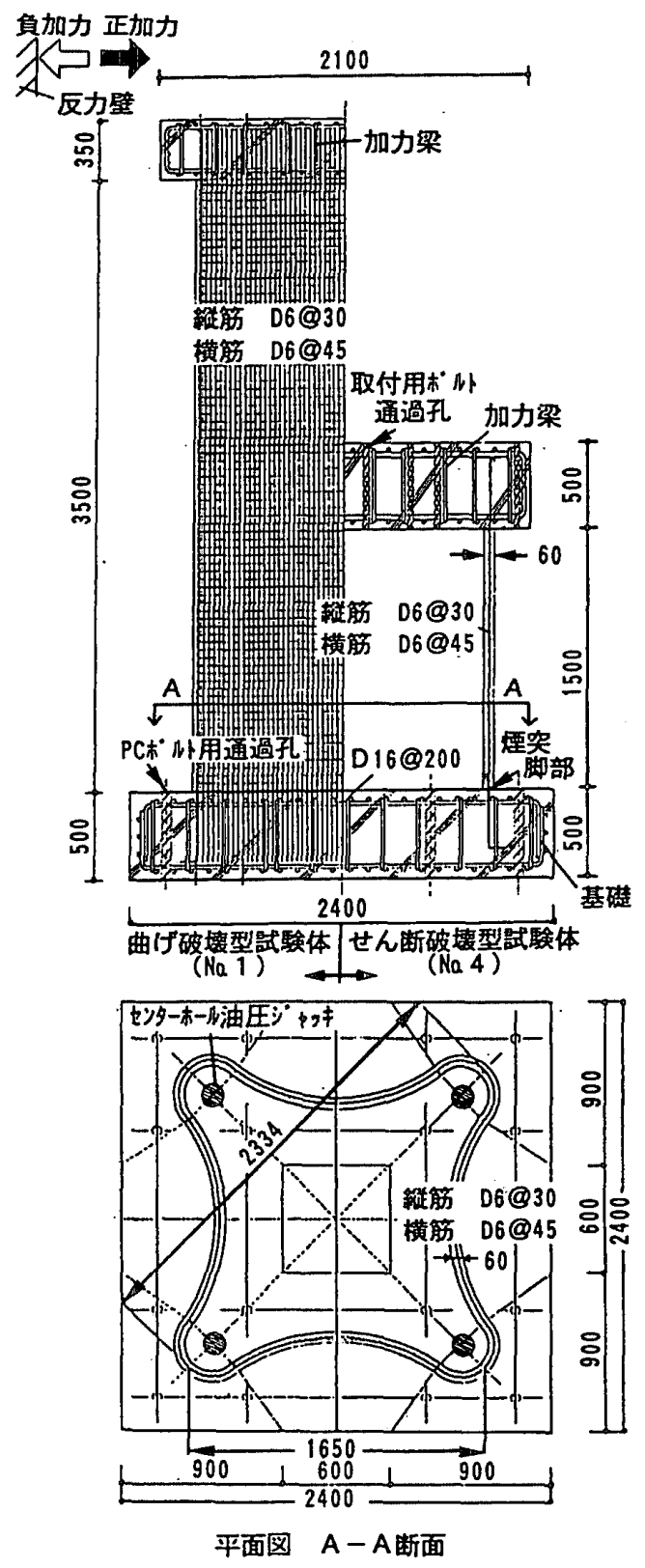

図一2 試験体の配筋図 $[$ No. 1，4] 
と解析結果との比較) の終局荷重 $Q_{u}$ の CAL 2/CAL 1 の值が 1.5 以上の場合を曲げ破壊型， 1.3 以下の場合を せん断破壊型と称した。

\section{(1) 曲げ破壊型試験体}

No. 1, No.2, No.6, No.7は，曲げ破壤を想定した 加力方向が $90^{\circ}$ または $0^{\circ}$ の試験体である。このうち, No. 6, No. 7 は有開口試験体で, 加力方向に対する開口 を変えてある。

No. 3, No. 8 は, 曲げ破壊を想定し, 加力方向が $45^{\circ}$ の試験体である。以上の 6 体の加力点高さは $h=5.00 \mathrm{~m}$ とした。

\section{（2）せん断破壊型試験体}

No. 4，No. 5 は，せん断破壊を想定した試験体で，加 力点高さは $h=1.75 \mathrm{~m}$ とした。

No. 4 は $90^{\circ}$ 方向加力, No. 5 は $45^{\circ}$ 方向加力とした。

有開口試験体 No.6, No.7, No. 8 を含む 8 体の試験 体とも，断面の基本寸法は同一であり，材料の仕様も同 一である。

\section{2 開口部の補強方法}

図一3 に有開口試験体 No. 6, No.7, No.8の開口周 囲の配筋詳細を示す。
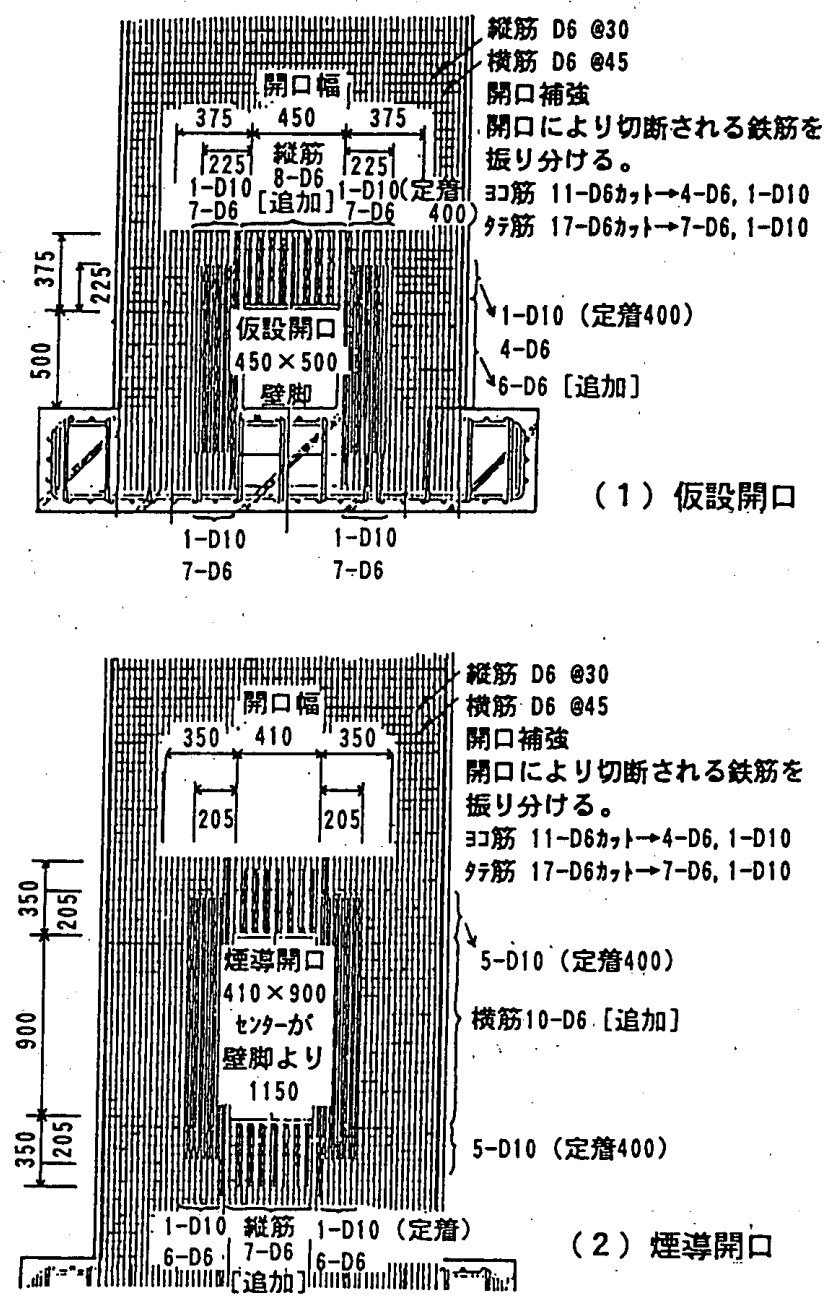

図一3 開口部配筋詳細
試験体の開口まわりの補強方法は, ACI の方法 ${ }^{14}$ お よび鉄筋コンクリート構造計算規準第 18 条耐震壁 ${ }^{15}$ に 準じて行い，以下の要領とした。

(a) 開口周辺部 $L / 2$ ( $L$ : 開口部短辺の長さ) 部分に は，仮設開口では半開口によって切られる鉄筋と同等量 の縦筋を，煙導開口では半開口によって切られる鉄筋量 の 1.1 倍の縦筋を追加して配筋する。すなわち，この範 囲では縦筋量がそれぞれ 2 倍，2.1 倍となる。

（b）横筋は半開口によって切られる補強筋量と同等量 の横筋を，煙導開口部上下 $L / 2$ の範囲に追加して配筋 する。すなわち，この領域では横筋量が 2 倍となる。

（c）開口まわりには，開口の辺りに直交する鉄筋（直 交筋）を縦・横筋の $1 / 2$ の量だけ追加して配筋する。

(d ） (a)，(b) で追加する鉄筋の定着長は，開口部の 面より $L / 2$ とする。(c) で追加する直交筋の定着長は, $5 / 6 L(5 / 6 L$ は $L / 2+$ 鉄筋定着長) とする。ただし， 鉄筋定着長は本実験では $L / 3$ とし, 必要定着長 $30 d(d$ ：鉄筋公称径）以上を確保するものとした。

\section{3 実験方法}

図一4に曲げ破壊型試験体（No.1，2，3，6，7，8）の 載荷装置図を，図一5にせん断破壇型試験体（No.4，5）

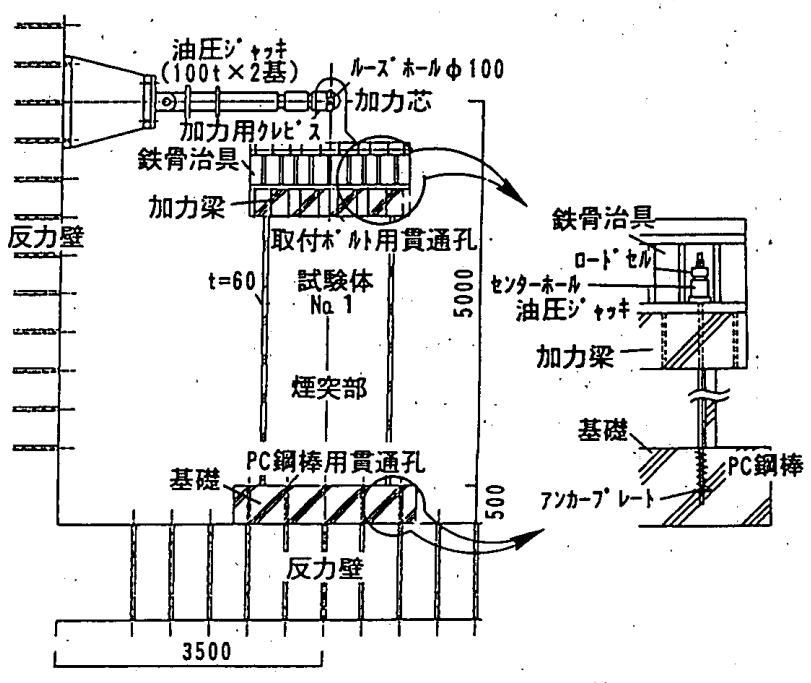

（a）水平力载荷方法

（b）轴力載荷方法

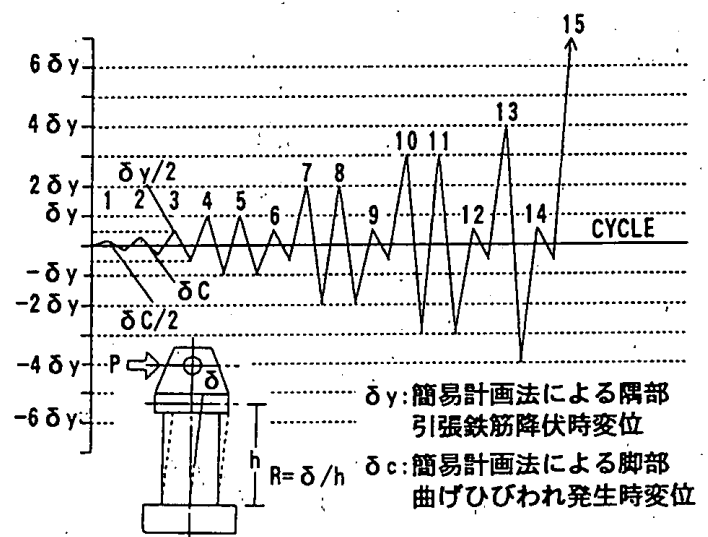

（c）載荷計画

図一4 載荷方法 [No. 1, 2, 6, 7, 3, 8] 


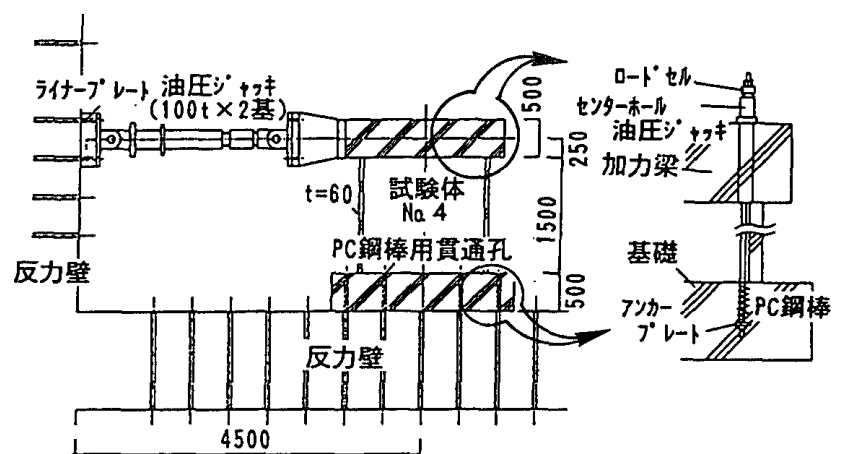

（a） 水平力截荷方法

（b）軸力載荷方法

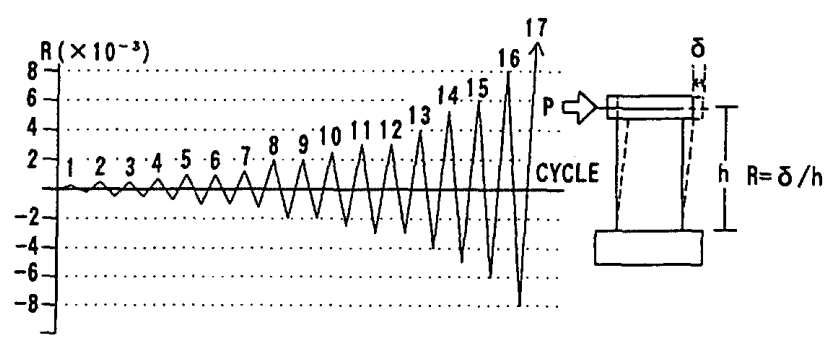

（c）載荷影画

図一－載荷方法 [No. 4, 5]

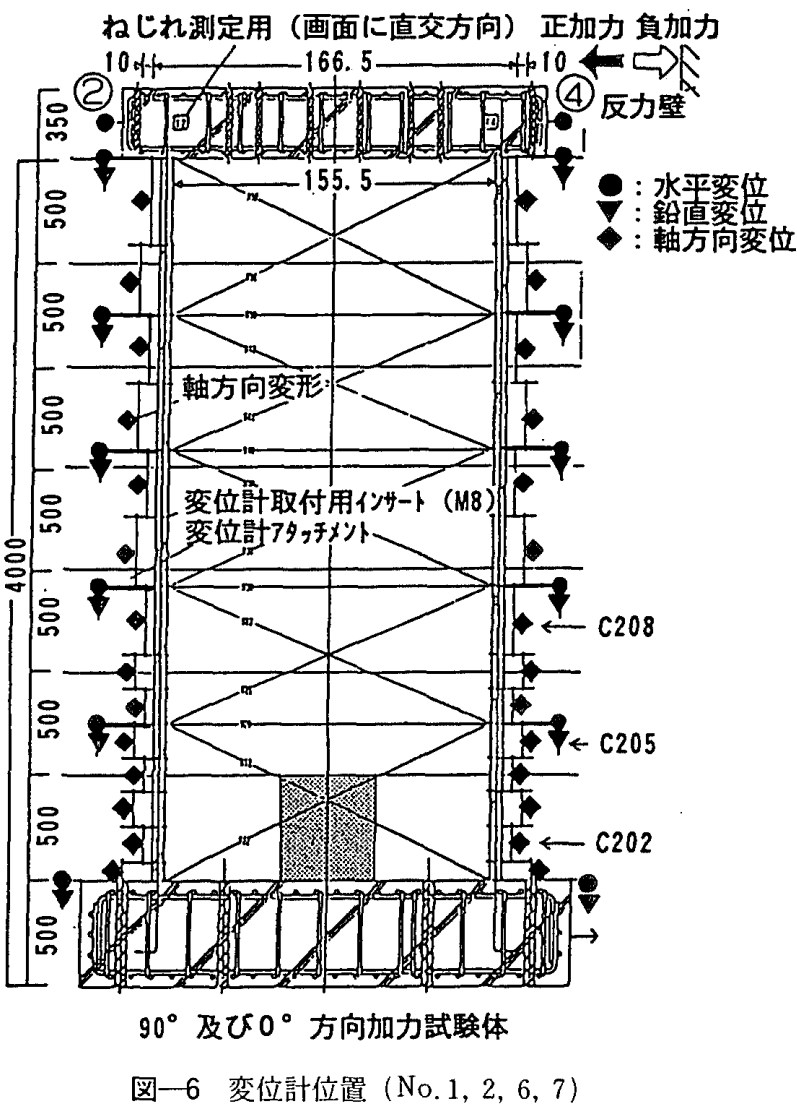

の載荷装置を示す。水平力は, 試験体上部に設置した加 力治具に取り付けた 2 本の油圧ジャッキにより載荷し, 実験中は試験体にねじれが生じないように，2本の ジャッキの変位が同一変位となるように制御した。

また，軸力は図一4(b) および図一5(b)に示すように， 加力梁の上に設けた加力治具に取り付けた 4 本のセン ターホール油王ジャッキにより載荷し, 奏験中一定値に
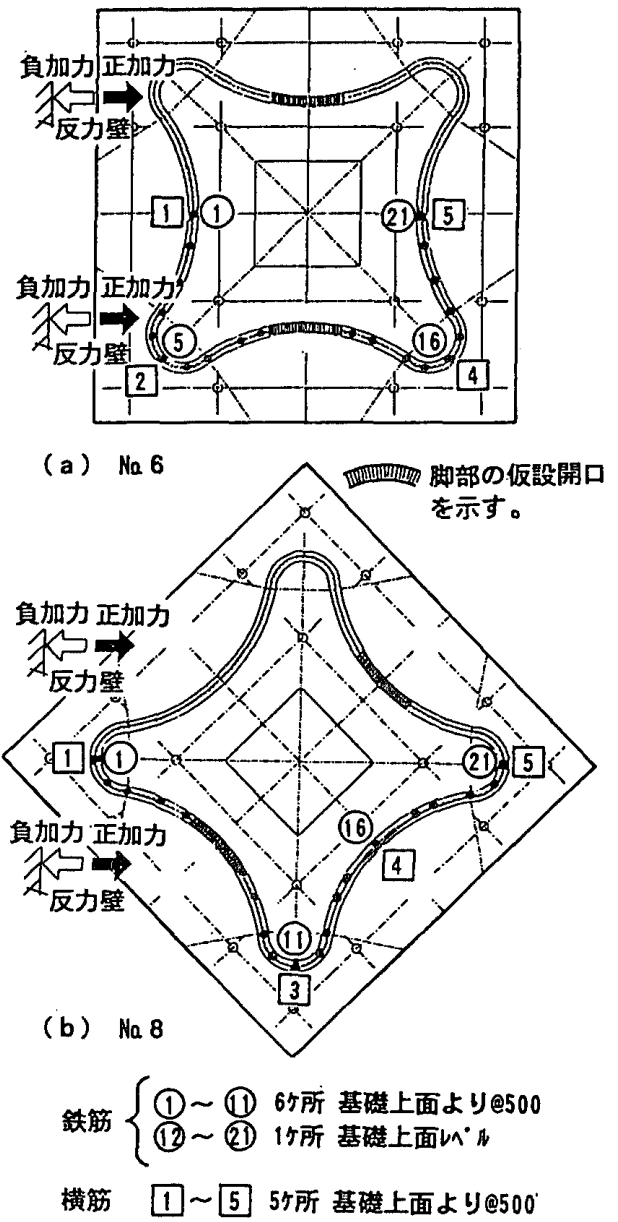

図一7 煙突脚部鉄筋歪測定位置

なるように保持した。載荷した軸力は煙突脚部の長期軸 力を想定し, 応力度にして $\sigma_{0}=27 \mathrm{~kg} / \mathrm{cm}^{2}$ である。

\section{4 測定方法}

図一6, 図一7 に変位計, 鉄筋歪ゲージの位置を示す。 変位は, 水平, 鈶值変位とも試験体の断面の 4 隅におい て測定を行った。また，曲げ変形算定用としては，試験 体の加力方向に対して圧縮側および引張側となる隅部 に，鉛直方向に並べて埋込まれたポルト間の軸方向変位 を测定した。

\section{5 使用材料の性質}

表一2 にコンクリートの配合表を示し，表一 3 に鉄筋

表一2 コンクリート・モルタルの配合表

\begin{tabular}{|c|c|c|c|c|c|c|c|c|}
\hline & $F_{c}$ & $W / C$ & S/a & W & C & $S$ & G & \multirow{2}{*}{$\frac{\mathrm{Ae}}{\mathrm{\ell} / \mathrm{m}^{2}}$} \\
\hline & $\mathrm{kg} / \mathrm{cm}^{2}$ & $\%$ & \% & \multicolumn{4}{|c|}{$\mathrm{kg} / \mathrm{m}^{3}$} & \\
\hline 妿力梁，基熱 & $\begin{array}{l}350 \\
300\end{array}$ & & 42.0 & $\begin{array}{l}192 \\
285\end{array}$ & $\begin{array}{l}480 \\
455\end{array}$ & \begin{tabular}{r|}
671 \\
1485 \\
\end{tabular} & 943 & 1.68 \\
\hline
\end{tabular}

表一3 鉄筋引張試験

\begin{tabular}{|c|c|c|c|c|c|}
\hline 径 & $\begin{array}{c}\text { 公称断面㺓 } \\
\left(\mathrm{cm}^{2}\right)\end{array}$ & $\mathrm{Na}$ & $\begin{array}{l}\text { 降伏強度 } \\
\left(\mathrm{kg} / \mathrm{cm}^{2}\right)\end{array}$ & $\begin{array}{l}\text { 引張強度 } \\
\left(\mathrm{kg} / \mathrm{cm}^{2}\right)\end{array}$ & $\begin{array}{c}\text { 伸ひ率 } \\
(x)\end{array}$ \\
\hline \multirow[t]{2}{*}{ D6 } & \multirow[t]{2}{*}{0.32} & $\begin{array}{l}1 \\
2 \\
3\end{array}$ & $\begin{array}{l}4131.3 \\
4225.0 \\
4140.6\end{array}$ & $\begin{array}{l}6281.3 \\
6250.0 \\
6264.5\end{array}$ & $\begin{array}{l}15.41 \\
14.38 \\
14.89\end{array}$ \\
\hline & & AV & 4165.6 & 6265.3 & 14.89 \\
\hline
\end{tabular}


表一4 煙突壁部コンクリート材料強度試験結果

\begin{tabular}{|c|c|c|c|c|}
\hline \multirow[t]{2}{*}{$\mathrm{Na}$} & $\begin{array}{l}\text { 㰣部から } \\
\text { の高さ }\end{array}$ & $\begin{array}{c}\text { 压樎強度 } \\
\sigma_{\mathrm{a}}\end{array}$ & $\begin{array}{c}\text { 割裂強度 } \\
\sigma_{\text {， }}\end{array}$ & $\begin{array}{c}\text { ヤダ的数 } \\
E C\end{array}$ \\
\hline & m & $\mathrm{kg} / \mathrm{cm}^{2}$ & $\mathrm{~kg} / \mathrm{cm}^{2}$ & $\times 10^{5} \mathrm{~kg} / \mathrm{cm}^{2}$ \\
\hline 1 & $\begin{array}{l}0.5 \sim 1.0 \\
1.0 \sim 2.0 \\
\text { 2. } 0 \sim 4.0\end{array}$ & $\begin{array}{l}306.1 \\
365.9 \\
326.2\end{array}$ & $\begin{array}{l}22.0 \\
21.5 \\
28.3\end{array}$ & $\begin{array}{l}2.02 \\
2.12 \\
1.90\end{array}$ \\
\hline 2 & $\begin{array}{l}0.5 \sim 1.0 \\
1.0 \sim 2.0 \\
2.0 \sim 4.0\end{array}$ & $\begin{array}{l}371.6 \\
378.1 \\
335.0\end{array}$ & $\begin{array}{l}32.7 \\
26.2 \\
23.0\end{array}$ & $\begin{array}{l}1.91 \\
2.07 \\
1.95\end{array}$ \\
\hline 3 & $\begin{array}{l}0.5 \sim 1.0 \\
1.0 \sim 2.0 \\
2.0 \sim 4.0\end{array}$ & $\begin{array}{l}316.0 \\
323.8 \\
381.2 \\
\end{array}$ & $\begin{array}{l}30.4 \\
28.0 \\
34.0 \\
\end{array}$ & $\begin{array}{l}1.71 \\
1.62 \\
1.95 \\
\end{array}$ \\
\hline 4 & $0.5 \sim 2.0$ & 350.9 & 33.2 & 2.03 \\
\hline 5 & $0.5 \sim 2.0$ & 310.3 & 23.3 & 1.90 \\
\hline 6 & $\begin{array}{l}0.5 \sim 1.0 \\
1.0 \sim 2.0 \\
2.0 \sim 4.0\end{array}$ & $\begin{array}{l}343.1 \\
357.6 \\
362.3 \\
\end{array}$ & $\begin{array}{l}24.9 \\
26.3 \\
29.8 \\
\end{array}$ & $\begin{array}{l}1.80 \\
1.95 \\
1.96 \\
\end{array}$ \\
\hline 7 & $\begin{array}{l}0.5 \sim 1.0 \\
1.0 \sim 2.0 \\
2.0 \sim 4.0\end{array}$ & $\begin{array}{l}380.8 \\
387.9 \\
354.9\end{array}$ & $\begin{array}{l}35.0 \\
36.9 \\
33.7\end{array}$ & $\begin{array}{l}1.97 \\
2.07 \\
1.97\end{array}$ \\
\hline 8 & $\begin{array}{l}0.5 \sim 1.0 \\
1.0 \sim 2.0 \\
\text { 2. } 0 \sim 4.0\end{array}$ & $\begin{array}{l}307.0 \\
320.6 \\
387.3 \\
\end{array}$ & $\begin{array}{l}26.4 \\
24.9 \\
34.0 \\
\end{array}$ & $\begin{array}{l}1.93 \\
1.67 \\
2.04\end{array}$ \\
\hline
\end{tabular}

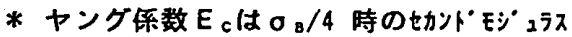

の引張試験結果を, 表一 4 に試験体煙突部の材料試験結 果を示す。

試験体の基礎および加力梁は骨材粒径 $15 \mathrm{~mm}$ の早強 コンクリートとし, 煙突壁部は骨材粒径 $5 \mathrm{~mm}$ の普通コ ンクリートとした。試験体への打設前に 2 回の試験練り を行い, 調合を決定した。煙突壁部のコンクリート打設 は縦打ちとし， 1 回の打設高さは $1 \mathrm{~m}$ を基準とした。

\section{3. 実験結果}

図一8〜11に最終破壊状況, 荷重一水平変位曲線を示 す。図中に, ひび割れ荷重時, 鉄筋降伏時, 圧壊時の荷 重を表示した。

試験体の破壊経過の概要は，以下のとおりである。

(1) 無開口試験体 No.1, No.2

壁脚部の曲げひび割れ発生

曲げせん断ひび割れ発生

壁脚部引張鉄筋降伏

最大荷重

壁脚部隅部の圧壊

\section{(2)，有開口試験体 No.6，No.7}

フラランジ部の煙導開口隅角部の斜めひび割れ発生 壁脚部の曲げひび割れ発生

曲げせん断ひび割れ発生

壁脚部引張鉄筋降伏

最大荷重

開口部下部の圧壊

急激な耐力低下となる。

(3) 無開口斜加力試験体 No. 3 壁脚部隅部の曲げひび割れ発生

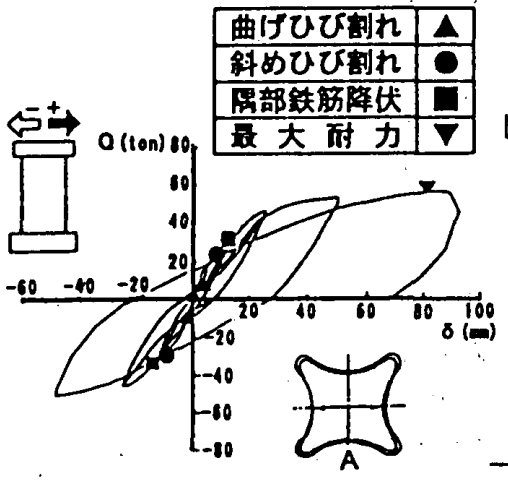

(1) Ma. 1

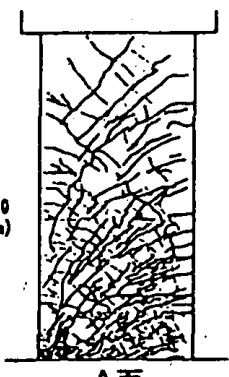

A面

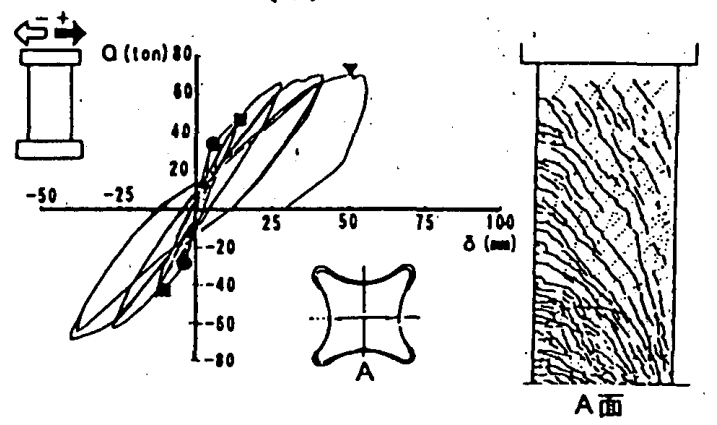

(2) Na 2

図一8荷重・変位曲線（無開口試験体）

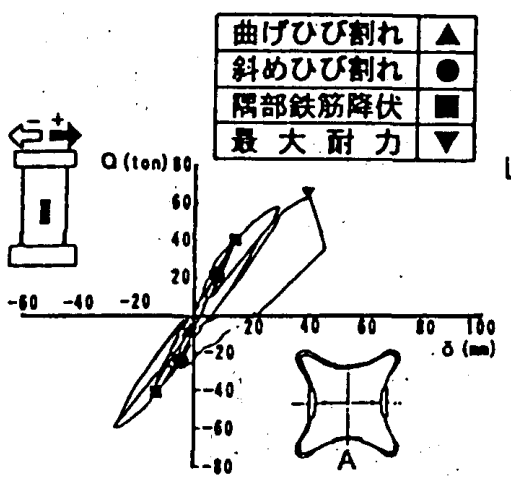

(3) $\mathrm{Ha} 6$

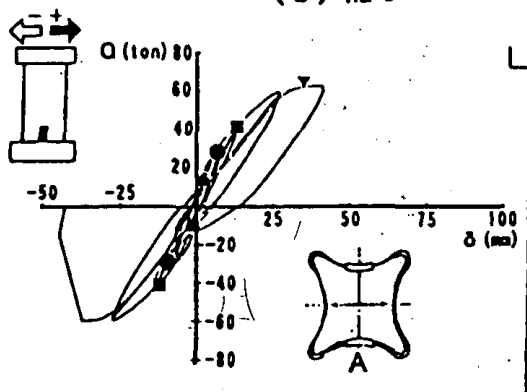

(4) $\mathrm{He} 7$

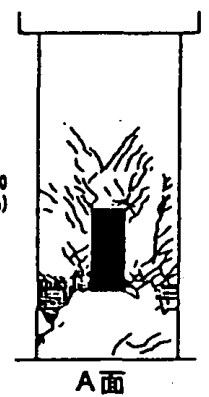

図一9 荷重・変位曲線（有開口試験体）

曲げせん断ひび割れ発生

壁脚部引張鉄筋降伏

最大荷重

壁脚部隅部の圧壊

（4）有開口斜め加力試験体 No.8

煙導開口隅角部の斜めひび割れ発生 
壁脚部隅部の曲げひび割れ発生

曲げせん断ひび割れ発生

壁脚部隅部引張鉄筋降伏

最大荷重

開口部下部の圧壊
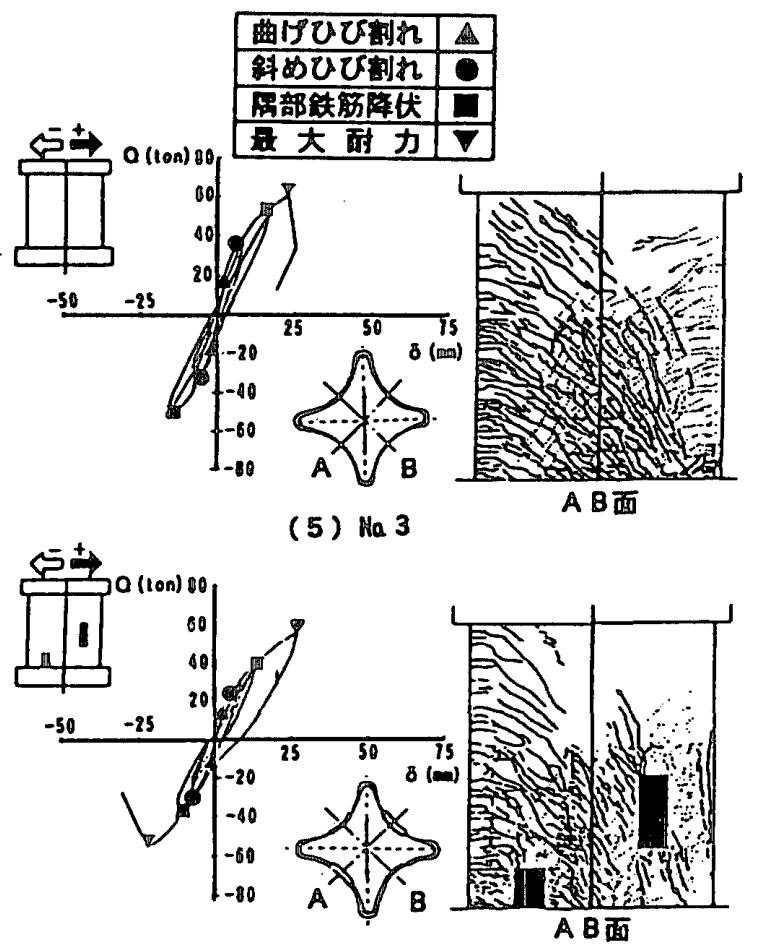

(6) Na 8

図一10 荷重・変位曲線（斜加力試験体）

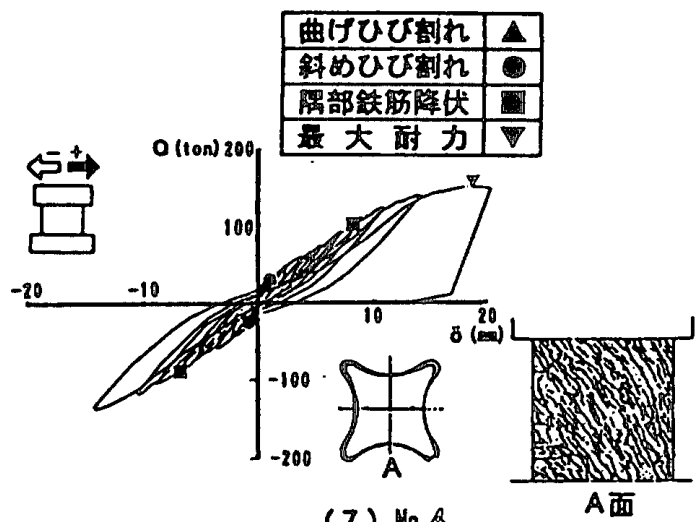

(7) $\mathrm{Ha} \mathrm{B}$

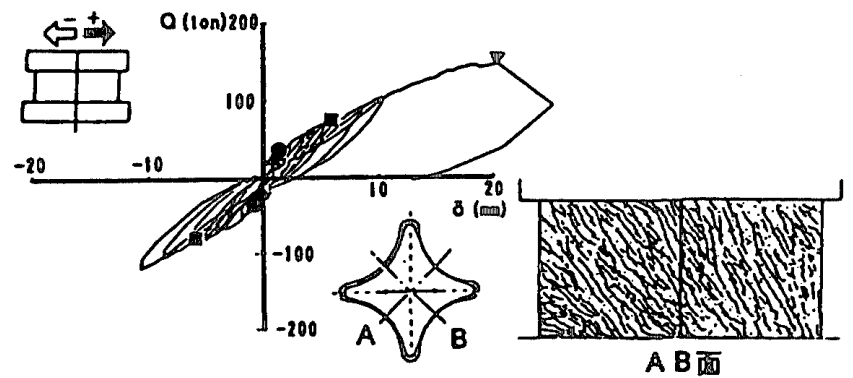

(8) $\mathrm{Ha} 5$

図一11 荷重・変位曲線（せん断破壊型試験体）
（5）せん断破壊型 $90^{\circ}$ 加力試験体 No.4

壁脚部の曲げひび割れ発生

せん断ひび割れ発生

壁脚部引張鉄筋降伏

最大荷重

せん断すべり破壊（斜めひび割れに沿う）

（6） せん断破壊型斜め加力試験体 No. 5

壁脚部隅部の曲げひび割れ発生

せん断ひび割れ発生

壁脚部引張鉄筋降伏

最大荷重

せん断すべり破壊（圧縮側にて）

\section{4. 実験結褁の考察}

\section{1 鉄筋の歪分布}

図一 12 , 図一13 に脚部隅部引張鉄筋降伏時の縦筋の 昰分布を示す。

開口の有無にかかわらず，各試験体とも壁の引張側フ ランジ部に相当する測定点では, 隅部から降伏が始まる。
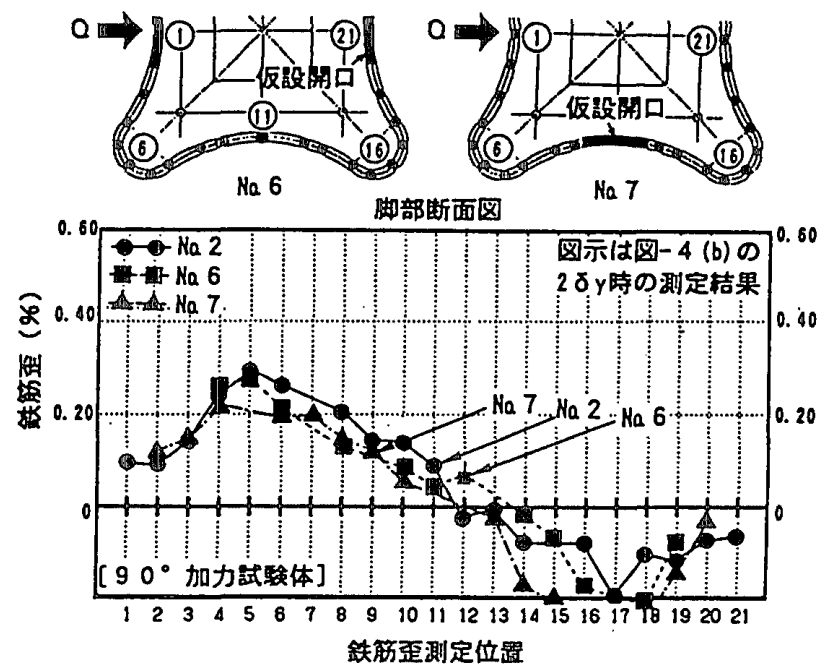

図-12 煙突壁脚部鉄筋歪分布
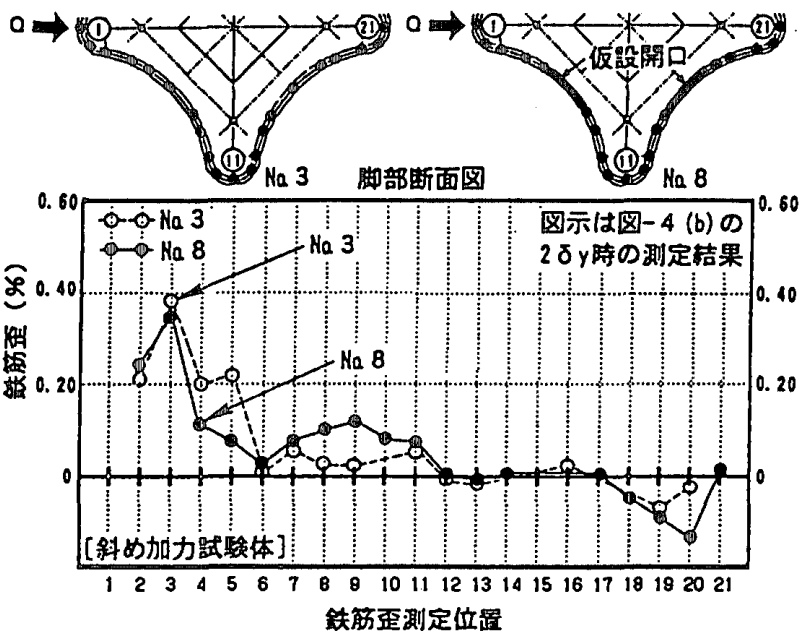

図一13 煙突壁脚部鉄筋歪分布 
有開口試験体 No.6, No.7 では，煙導開口によって 切断された縦筋の昰が小さく, 昰分布も開口位置で不連 続となっている。

4.2 曲げ変形, せん断変形の算出

図一6に示した試験体の軸方向変位より壁高さ方向の 曲率分布を求め，図一14に従い（1）式から曲げ変形 $\delta_{B}$ を算出した

$$
\delta_{B}=\sum_{i=1}^{n}\left\{\left(\Delta \delta L_{i}-\Delta \delta R_{i}\right) \cdot d H_{i} / L\right\}
$$

さらに，せん断変形 $\delta_{S}$ は，全体変形から曲げ変形 $\delta_{B}$ を差し引くことで求めることができる。

図一15〜図一17 に曲げ変形と全体変形の比を示す。

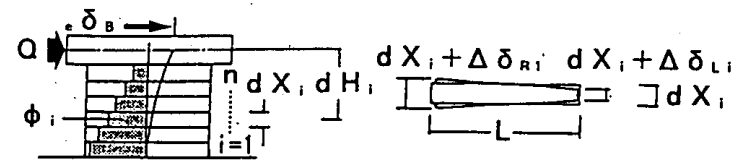

a) 曲率分布と曲げ変形 b) $i$ 区分の曲率 $\phi_{i}$ の求め方

図一14 曲げ変形計算の仮定

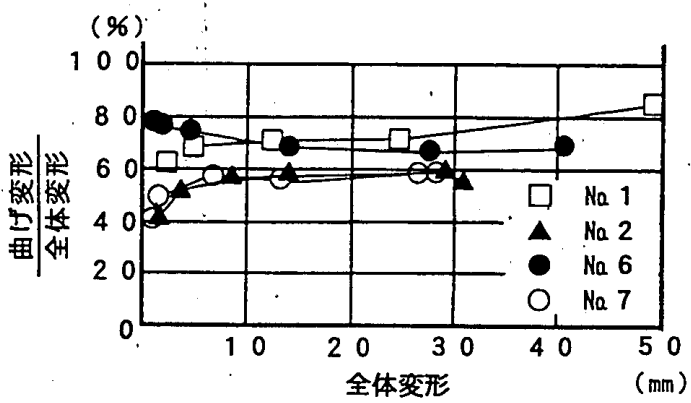

図一15 曲げ変形と全体変形

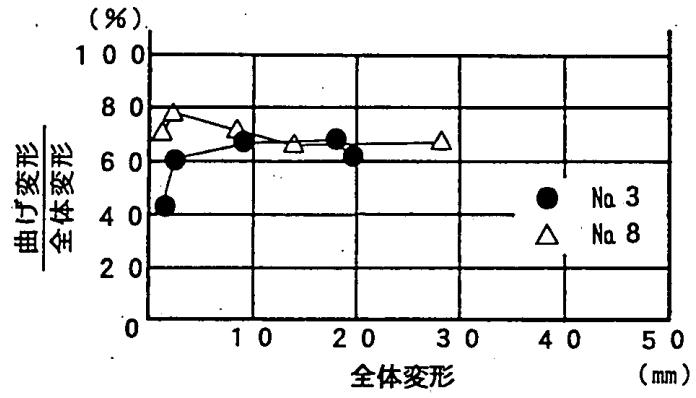

図一16 曲.゙変形と全体変形

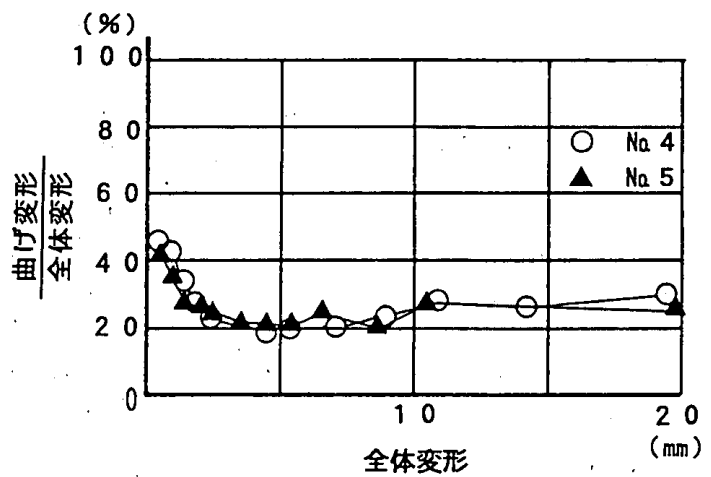

図一17曲げ変形と全体変形
図から，曲げ破壊型試験体では曲げ変形が全体変形の 60ー80\%となっている。隅部引張鉄筋,の降伏（ $\delta=10$ $\mathrm{mm})$ 後は曲げ変形と全体変形の比は一定となっている。

\section{5. 破壊包絡線の比較}

\section{1 軸力の影響}

図一18に；無開口で軸力 0 の No.1と，無開口で軸 力 $27 \mathrm{~kg} / \mathrm{cm}^{2}$ の No. 2 との破壊包絡線の比較を示す。

No. 2 は軸力の寄与だけ $15 \%$ ほど最大耐力が増加す るが，最大耐力時変位はNo. 1 に比べて約 $1 / 2$ に低下す る。

\section{2 開口による影響}

図一 19 に $90^{\circ}$ 加力で無開口の No. 2 と有開口の No. 6, No. 7 および斜め加力で無開口の No. 3 と有開口の No. 8 の破壊包絡線の比較を示す。

$90^{\circ}$ 加力では, 有開口のNo.6，7 とも降伏酎力は No. 2 の約 0.90 倍であるが，No.6，No. 7 の降伏時変位 はNo. 2 とほぼ同等である。最大耐力時変位は無開口の No. 2 では $4 \delta_{y}(R=1 / 67.5)$ であるが, 有開口の No. 6, No. 7 では $3 \delta_{y}(R=1 / 90)$ と, 多少低下している。

斜め加力では，有開口の No. 8 の最大耐力は無開口の No. 3 の約 $90 \%$ となっている。これは, $90^{\circ}$ 加力の場合 と同様な傾向である。しかし，斜め加力では最大耐力時 変位は無開口の No.3 と No.8.゙ほぼ同等である。
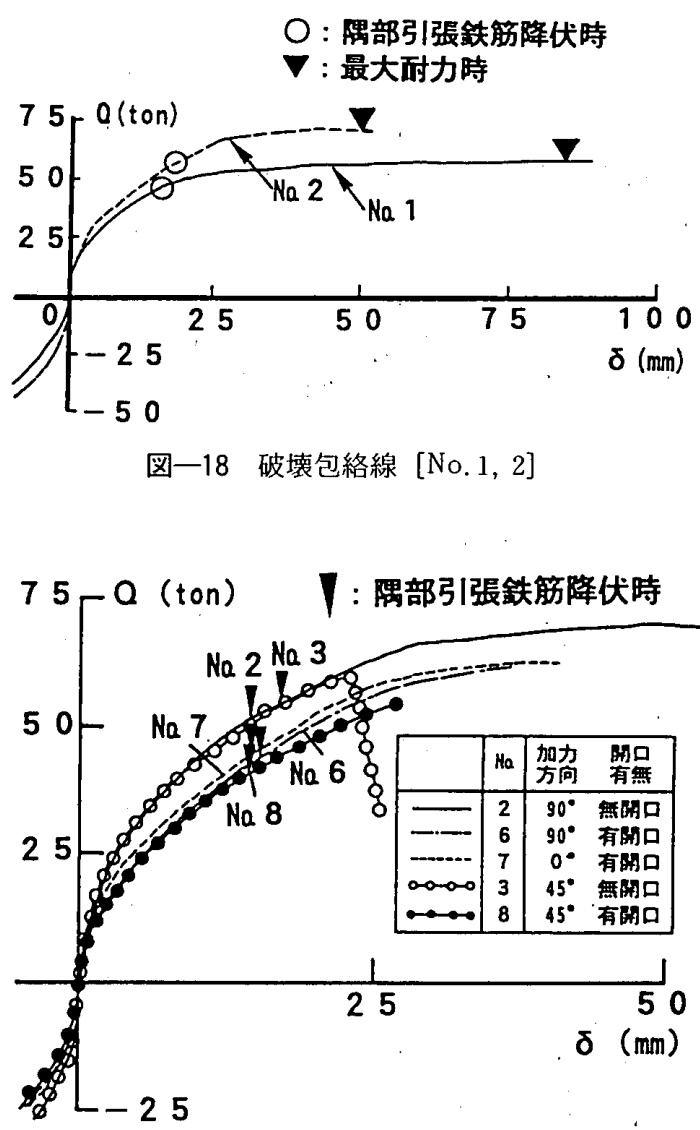

図一19破壊包絡線.[No. 2, 6, 7, 3, 8] 


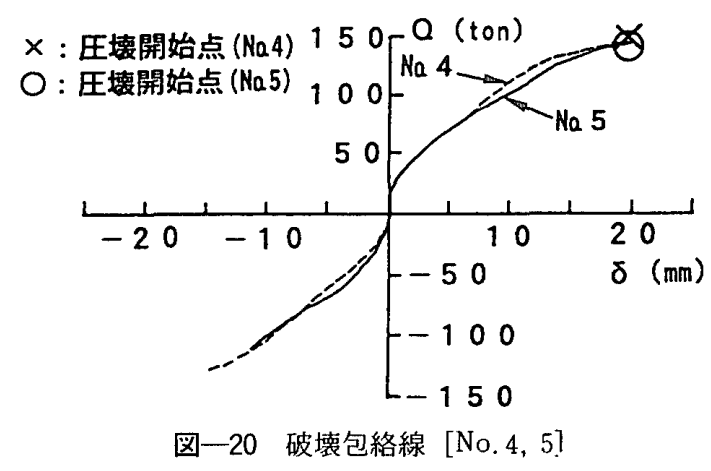

\section{3 加力方向の影響}

図一19 の破壊包絡線において, 無開口試験体につい て着目すると, $90^{\circ}$ 加力の No. 2 と斜加力の No. 3 で は, 変形が約 $15 \mathrm{~mm}$ までは斜め加力の No. 3 と $90^{\circ}$ 加 力のNo.2 の履歴はほぼ同様である。

しかし, 斜め加力の No. 3 では, 変形が約 $20 \mathrm{~mm}$ から, 王壊が始まり耐力が急激に低下し, 終局時変位は $90^{\circ}$ 加 力の No. 2 の約 $1 / 2$ に低下しており, 梅村ら ${ }^{11}$, 遠藤ら ボックス形立体耐震壁の実験結果とまったく異なった傾 向を示した。

同様に, 図一19 の破壞包絡線において, 有開口試験 体について着目すると, 斜め加力の No. 8 の耐力は $90^{\circ}$ 加力の No.6, No.7 に比べて $10 \%$ 程度低下している。 また, 斜め加力の No. 8 の終局時変位は $90^{\circ}$ 加力の No. 6, No. 7 の $2 / 3$ 程度に低下している。

5.4 女九断破壊型試験体

図一 20 に，せん断破壊型試験体で $90^{\circ}$ 加力の No. 4 と 斜め加力の No. 5 の破壊包絡線の比較を示す。

図に示すように，せん断破壊型試駼体では，No.4と No. 5 の破壊包絡線は破壊に至るまでほとんよ゙一致して いる。遠藤ら め加力の場合は約 $10 \%$ 最大耐力, 変形性能の上昇が見 られたが, 本実験では, 加力方向の影響はほとんどなかっ た。

\section{6. 復元力特性に関する検討}

6.1 簡易計算法による曲げ変形計算值の算定方法

試験体の断面を，図一21に示すように高さ方向に分 割し,さらに各高さごとに平面的に分割し, $e$ 関数法に 準じた方法で $M-\phi$ 関係を求め, 曲げに対する各耐力お よび変形を簡易的に算定した（以下の方法を簡易計算法 之呼ぶ）。

算定の手順は以下のとおりである。

(1) 断面を分割する

(2) 各要素の応力の算定

(3) 力の釣合条件

(4) 中立軸位置を求める

(5) モーメント $M$ を求める

$-62-$

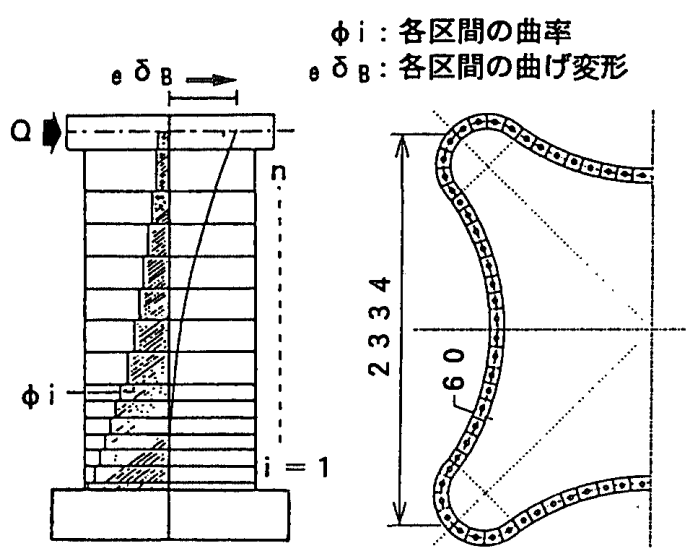

（1）高さ方向の分割

(2) 断面の分割

図一21試験体のモデル化

L : 開口部短刃長さ

$h_{0}$ : 開口の内のり高さ

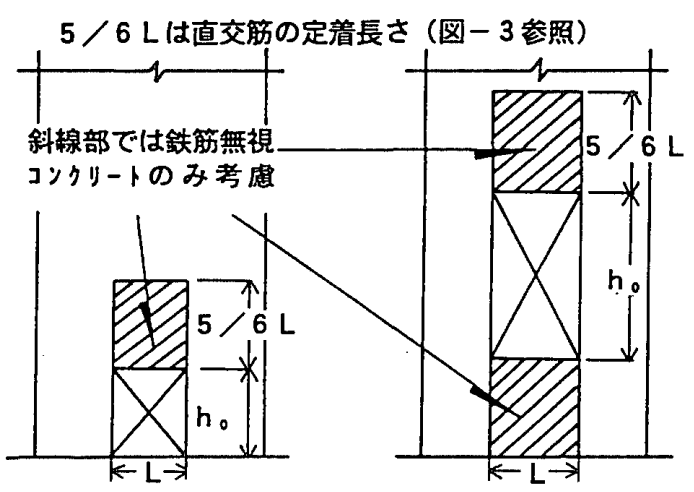

（1）仮設開口

(2) 煙導開口

図一22 開口周辺の仮定

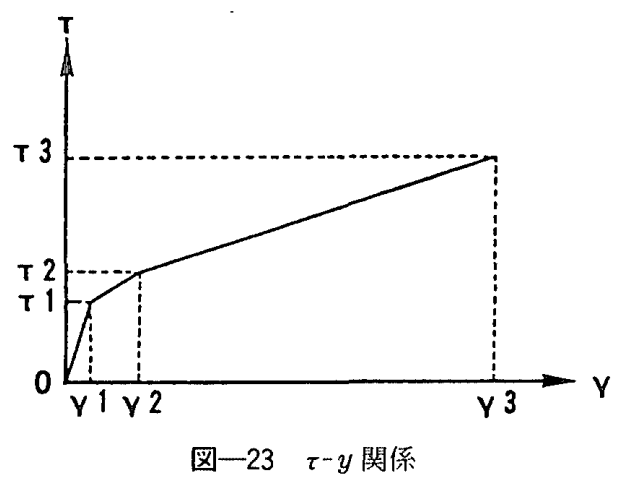

(6) 曲率 $\phi=1 / \rho$ を求める

(7) 高さ方向の曲率分布より曲げ変形を求める

この算定法では, 平面保持を仮定し, 鉄筋は壁芯位置 に集中するものとした。また，コンクリートの引張強度 は表一3の割裂強度とした。ただし，仮設開口，煙導開 ロでの縦筋およびコンクリートは, 図一 22 のように仮 定し, 縦筋は基礎内に十分定着されており抜け出しは無 視した。

6.2 せん断復元力特性の計算值の算定方法 せん断の復元力特性を図一 23 のような 3 折点からな 
る $\tau-\gamma$ 関係で表示し, 各折点および終局点を次式より 算定した。ただし，女ん断強度の算定に用いた有効断面 積は全断面積の $1 / 2$ とした ${ }^{16), 17 ! 。 ~}$

(1). 第 1 折点

$$
\begin{aligned}
& \tau_{1}=\sqrt{\sqrt{F_{c}}\left(\sqrt{F_{c}}+\sigma_{v}\right)} \\
& \gamma_{1}=\tau_{1} / G \cdots \cdots, \cdots \cdots \cdots \cdots \cdots
\end{aligned}
$$

(2) 第 2 折点

$\tau_{2}=1.35 \tau_{1}$

$\gamma_{2}=3 \gamma_{1}$

(3) 終局点

$$
\begin{array}{r}
\tau_{3}=\left\{1-\tau_{s} /\left(4.5 \sqrt{F_{c}}\right)\right\} \tau_{0}+\tau_{s} \\
\quad\left(\tau_{s} \leqq 4.5 \sqrt{F_{c}}\right) \\
=4.5 \sqrt{F_{c}} \quad\left(\tau_{s}>4.5 \sqrt{F_{c}}\right) \\
\gamma_{3}=4.0 \times 10^{-3} \ldots \ldots \ldots \ldots \ldots \ldots \ldots \ldots \ldots \ldots \ldots
\end{array}
$$

$$
\tau_{0}=(3-1.8 M / Q D) \sqrt{F_{0}}
$$$$
\text { ただし， } M / Q D>1 \text { のとき } M / Q D=1
$$$$
\tau_{s}=\left(P_{U}-P_{H}\right)_{s} \sigma_{y} / 2+\left(\sigma_{U}+\dot{\sigma}_{H}\right) / 2
$$

$F_{c}$ : コンクリートの圧縮強度 $\left(\mathrm{kg} / \mathrm{cm}^{2}\right)$

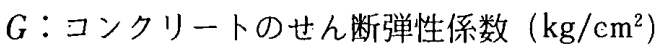

${ }_{c} E:$ : コンクートのヤング係数 $\left(\mathrm{kg} / \mathrm{cm}^{2}\right)$

$P_{U}, P_{H}:$ 縦, 横筋比 (実数)

$\sigma_{U}, \sigma_{H}$ : 縦, 横軸応力度 $\left(\mathrm{kg} / \mathrm{cm}^{2}\right)$ (王縮を正とする)

${ }_{s} \sigma_{y}:$ 鉄筋材料強度 $\left(\mathrm{kg} / \mathrm{cm}^{2}\right)$

$M / Q D:$ せん断スパン比

\section{3 実験値と計算值の比較}

表一 5 に，諸荷重の計算結果一覧を示す。

曲げひび割れの実験值は，曲げ破壊型試験体 No. 1, No. 2, No. 6, No. 7, No. 3 では簡易計算法により求め た計算值と比較的よく一致しているが斜め加力試験体 No.8, せん断破壊型試験体 No. 4, No. 5 では計算值よ りもかなり低い值となっている。
隅部引張鉄筋降伏荷重の実験值は, No.3 を除いて計 算值より. 14〜47\% 低い值となっている。ブランジ部引 張鉄筋降伏荷重の実験值は計算值と比較的一致してい る。

$90^{\circ}$ 加力試験体 No.2, No. 6, No.7 では, 終局荷重 実験値は簡易計算法により求めた計算値よよく一致して いるが，斜加力試験体 No. 3，No:8 では，実験值は 計算値より約 $20 \%$ ほど低い值を示した。

せん断破壊型試験体 No:4，5 では，終局荷重奏験值 はせん断終局強度計算值の約 $90 \%$ 之, 比較的よく一致 している。

\section{4 曲げ変形関係}

図一 24 , 図一 $25 に$, 簡易計算法で求めた荷重-曲げ変 形関係を示す。曲げ破壊型試験体 No. 2; No.6, No.7

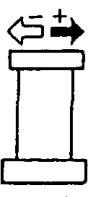

No 2

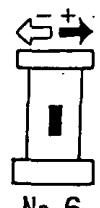

Na 6

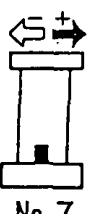

Na 6 . Na 7 については 原点をさ10m五らした。

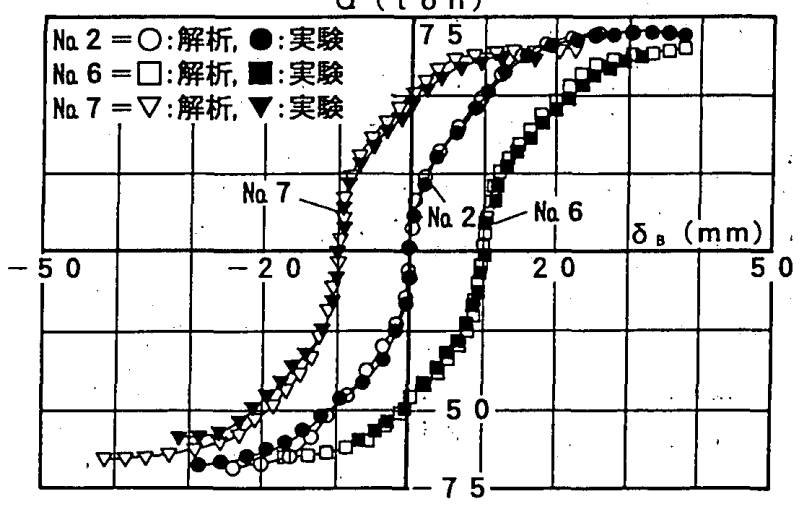

図一24 荷重-曲げ変形計算結果 (No. 2, 6, 7)

表一5 実験結果と解析結果の比較

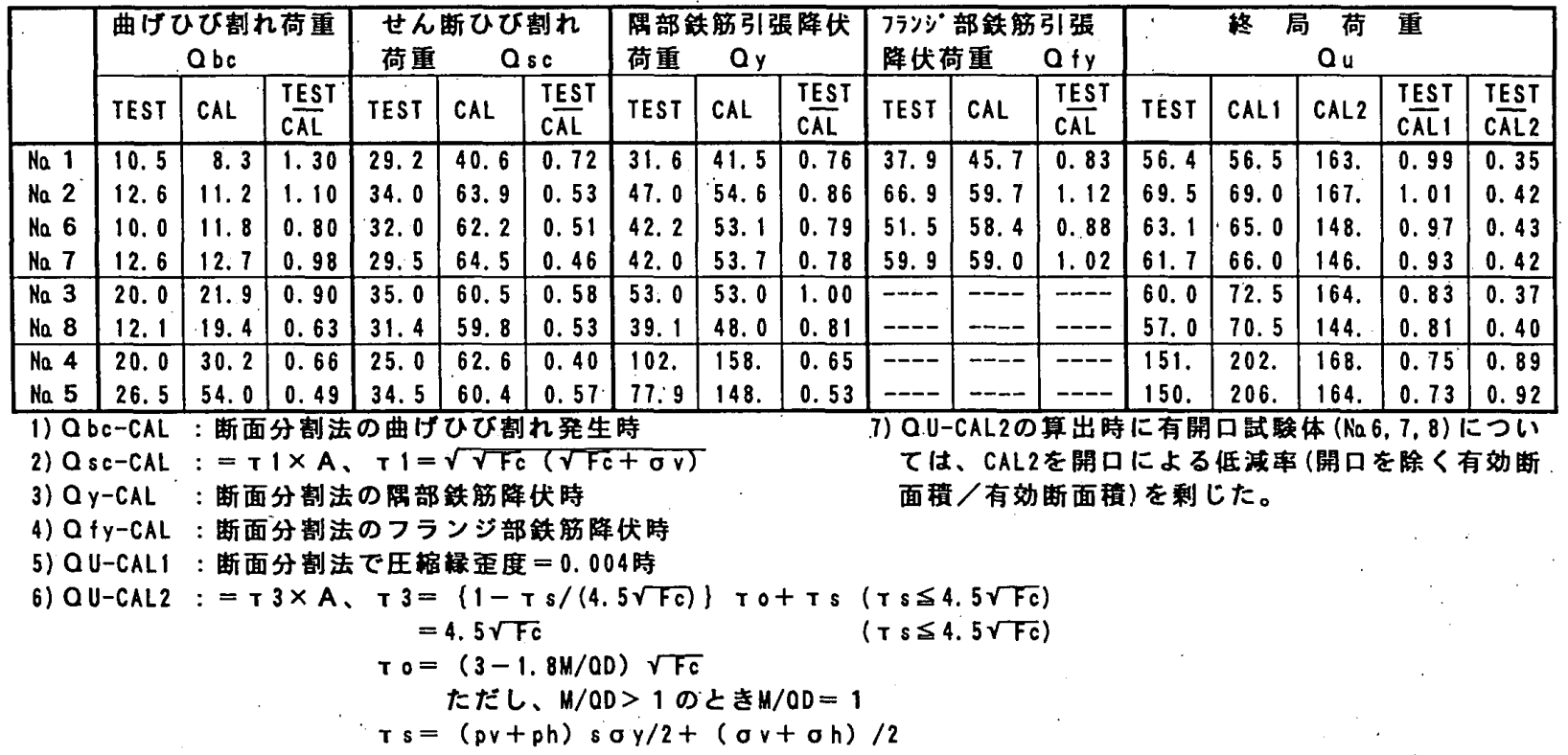




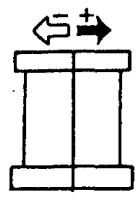

$\mathrm{Na} 3$

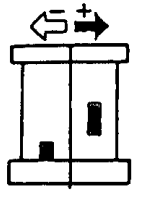

No. 8
Na 8 については原点を -10mi゙らした。

$0(t \circ n)$

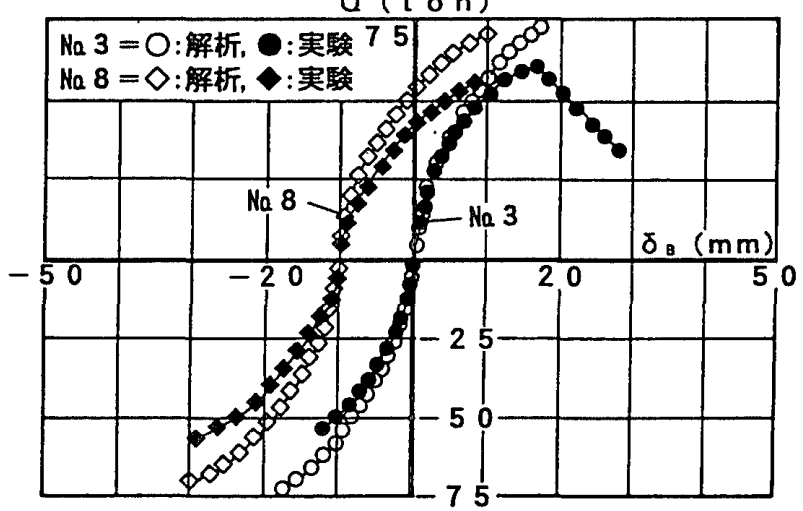

図一25 荷重-曲げ変形計算結果 (No.3, 8)

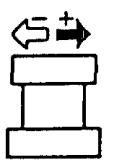

$\mathrm{Na} 4$

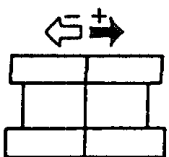

Na 5 $a(t \circ n)$

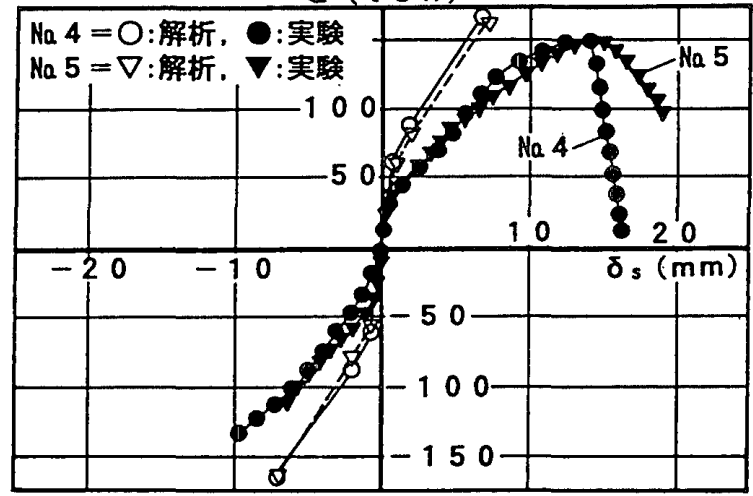

図一26荷重-せん断変形計算結果 (No. 4, 5)

では簡易計算法による曲線は実験結果と比較的よく対応 している。No.3，No.8では実験結果が簡易計算法によ る曲線を下回っている。

\section{5 せん断変形関係}

図一26に，せん断破壊型試験体 No. 4 , No. 5 の荷重せん断変形曲線を示す。第一折点之第 2 折点の実験值が 計算值の約 $50 \%$ と低く実験では接線剛性も低い。また， 終局点の変位も実験結果の最大耐力時変位の約 $1 / 2$ 之 なっている。これは, 試験体の壁厚が $60 \mathrm{~mm}$ と薄肉で あり製作時に生じた収縮ひび割れ等の初期ひび割れのた めと思われる。

\section{7.まとめ}

本研究は異型煙突の構造特性に影響を与える諸因子を 取り上げ，それらがどのような影響を及ぼすかを，奏験
による確認を行った。本実験条件の範囲で得られた成果 および結論をまとめると以下のようになる。

1）曲げ破壊型試験体では, 引張り側軸力を加えない試 験体では鉄筋降伏後も，荷重-変位関係で部材角にして $1 / 50$ まで耐力低下が起こらず安定した復元力特性が得 られた。また軸力を加えた無開口試験体では酎力が 15 \%ほよ゙増加したが，変形性能は軸力を加えない試験体 の約 $1 / 2$ に減少した。

2）有開口試験体は, 無開口試験体に比較して, 加力方 向にかかわらず，最大耐力は約 $90 \%$ であった。

3）斜め加力試験体では有開口, 無開口試験体とも $90^{\circ}$ 方向加力に比べ変形性能の低下がみられた。

4) 脚部の縦筋の歪分布測定結果より, 煙導開口部によ り切断される縦筋は曲げ耐力への寄与は少ないと考えら れる。

5) 曲げスケルトンカーブのモデル化に関しては簡易計 算法を提案した。曲げについては $0^{\circ}, 90^{\circ}$ 方向と $45^{\circ}$ 方 向では，実験結果と解析で多少の方向性が見られたが， 計算結果は実用上十分な精度であることが分かった。 6) せん断のスケルトンカーブのモデル化に関してはせ ん断スパン比の大きい煙突などは初期の曲げひび割れが せん断ひび割れに進展するため, 既往の算定式の $2 / 3$ 程 度であり，第一折点の評価には注意が必要である。

以上, 異型煙突の構造特性を决定する一因として, 開 口部, 加力方向, せん断スパン比, 複合応力などの影響 は大きく，構造設計に関してはこれらを考慮することが 望ましい。また，せん断に関してはさらに検討が必要で ある。

\section{謝 辞}

この超高異型煙突の構造に関する研究では，東京電力 (株) 建設部建築課の方々，同技術研究所の方々に御指 導や，貴重なデーターを発表する機会を与えて頂きまし た。また，日本国土開発(株)の方々には実験を行って 頂きました。さらに, 東京大学の青山教授に終始御指導 頂きました。厚く御礼申しあげます。

\section{参考文献}

1）表佑太郎，武田寿一：鉄筋コンクリート造煙突の弾塑性 忍答に関する研究 (その一1・模型実験と解析), 日本建 築学会論文報告集, 第 215 号, pp. $21 \sim 29$, 昭和 49 年 1 月

2）武藤 清，太田外気晴，内田一義：超高 $\mathrm{RC}$ 造煙突の振 動実験，日本建築学会論文報告集，第 208 号，pp. 1 13, 昭和 48 年 6 月

3）内田一義：超高 RC 造煙突の動的耐震設計法に関する研 究，日本建築学会論文報告集，第 211 号，pp. 27 35, 昭和 48 年 9 月

4）日本建築学会：鉄筋コンクリート煙突の構造設計指針, 昭和 51 年 6 月

5）日本建築センター：煙突構造設計施工指針，昭和 57 年 
6）瀬戸川葆：円筒型鉄筋コンクリート耐震壁に関する水平 加力実験, 日本建築学会論文報告集, 第 290 号, pp. 57 $\sim 67$, 昭和 55 年 4 月

7) 高山 誠, 半谷裕彦：搭状型鉄筋コンクリート円筒シェ ルに関する研究，シェアスパン比の影響について，日本 建築学会大会学術講演梗概集, pp. 1697 1698, 昭和 58 年 9 月

8）小垣善一, ほか 5 名：円筒型 RC 耐震壁に関する弾塑性 応答解析（数值計算例 その $1,2,3$ ), 日本建築学会近 畿支部, 研究報告集, pp. 105 116

9）斉藤英明：鉄筋コンクリート製格納容器の開発（その2） 開口のある内筒モデルの稀じり加力実験, 日本建築学会 大会学術講演梗概要集, pp. 1233 1234, 昭和 63 年 10 月

10）内田 孝，ほか 4 名：原子炬発電用鉄筋コンクリート造 格納容器の事故時内圧・水平同時加力模型実験（その1 一 その 5), 日本建築学会大会学術講演梗概集, pp. 1827 $\sim 1832$, 昭和 54 年 9 月

11）梅村 魁, 青山博之, 細川洋治：鉄筋コンクリート立体 耐震壁の耐力之復元力特性に関する実験的研究（その 1 一その 3), 日本建築学会大会学術講演梗概集, pp. 1577 $\sim 1582$, 昭和 51 年 10 月
12）遠藤彰, 渡辺丹ほか:二方向入力によるボックス壁 の力学性状に関する実験的研究 (その 1 , その 2), 日本 建築学会大会学術講演梗概集, pp. 827 830, 昭和 60 年 10 月

13）坂元健一朗，三㼛昭彦ほか：建屋の復元力特性に関する 研究 (その 2 その5)：日本建築学会大会学術講演梗概 集, pp. 1497 1504, 昭和 58 年 9 月

14) Specification for the Design and Construction of Reinforced Concrete Chimneys (ACI 307-69), Chapter 4-4.4

15) 日本建築学会：鉄筋コンクリート構造計算規準, 昭和 63 年

16）吉崎征二, 田中宏志：原子炉建屋鉄筋コンクリート耐震 壁の復元力特性評洒法（その2・収集データの分析及び 文献), 日本建築学会大会学術講演梗概集, pp. 291 292, 昭和 62 年 10 月

17）古川 茂, 田中宏志, 井元勝慶, 吉崎征二：原子炉建屋 鉄筋コンクリート耐震壁の復元力特性評価法（その 1 ・ 復元力特性評価法), 日本建築学会大会学術講演梗概集, pp. $289 \sim 290$, 昭和 62 年 10 月

(1992 年 11 月 20 日原稿受理, 1993 年 6 月 29 日採用決定) 